\title{
Calendar of Meetings
}

\author{
Donald R. Petersen \\ Greenleaf Associates \\ 6210 Siebert Street \\ Midland, MI 48640-2724, USA \\ drpeterson@tm.net
}

\section{4-18 March 2005}

International Centre for Diffraction Data, Spring Meeting. Newtown Square, Pennsylvania, USA. [Contact: Linda Shertz, International Centre for Diffraction Data, 12 Campus Boulevard, Newtown Square, PA 19073-3273, USA. Tel: 1 (610) 325 9814; Fax: 1 (610) 325 9823; E-mail: shertz@icdd.com; Info: http://www.icdd.com].

\section{March-1 April 2005}

Materials Research Society Spring Meeting. San Francisco, California, USA. [Contact: Materials Research Society, 506 Keystone Drive, Warrendale, PA 15086-7573, USA. Tel: 1 (724) 779 3003; Fax: 1 (724) 779 8313; E-mail: info@mrs.org; Info: http://www.mrs.org].

\section{March-1 April 2005}

Crystal 24. The 24th Biennial Conference of the Society of Crystallographers in Australia and New Zealand. Marysville, Australia. [Contact: E-mail: crysta124@csiro.au; Info: http://xrsi.cmit.csiro.au/Crystal24].

\section{0-13 April 2005}

107th Annual Meeting and Exposition of The American Ceramic Society. Baltimore, Maryland, USA. [Contact: The American Ceramic Society, 735 Ceramic Place, Westerville, OH 43081, USA. Tel: 1 (614) 794 5890; Fax: 1 (614) 794 5892; E-mail: info@ceramics.org; Info: http:// www.ceramics.org/meetings].

\section{2-14 April 2005}

British Crystallographic Association Annual Spring Meeting. Loughborough, England, United Kingdom. [Contact: Info: http://crystallography.org.uk].

\section{2-26 May 2005}

3rd Meeting of the International Union of Microbeam Analysis Societies, held together with the 9th EMAS Workshop on Modern Developments and Applications in Microbeam Analysis, Florence, Italy. [Contact: European Microbeam Analysis Society Secretariat, University of Antwerp, Department of Chemistry, Attn: Mr. Luc Van't dack, Universiteitsplein 1, BE-2610 Antwerp-Wilrijk, Belgium. Tel: 32 (3) 82023 43; Fax: 32 (3) 82023 43; E-mail: Luc.Vantdack@ua.ac.be; Info: http://www.emas-web.net/ Content/EMAS2005.htm].

28 May-2 June 2005

American Crystallographic Association Annual Meeting. Orlando, Florida, USA. [Contact: Khalil Abboud at abboud@chem.uff.edu; Ed Collins at edward_collins@ med.unc.edu; Info: http://www.hwi.buffalo.edu/ACA].

\section{June-1 July 2005}

Joint 20th AIRAPT-43rd EHPRG International Conference on High Pressure Science and Technology. Karlsruhe, Germany. Associated with the 7th EMU School in Mineral Behaviour at Extreme Conditions in Heidelberg, 19-28 June. [Contact: Prof. Dr. Eckhard Dinjus, Forschungszenrum Karlsruhe (ITC-CPV), PO Box 3640, D-76021 Karlsruhe, Germany. Tel: 49 (7247) 8224 00; Fax: 49 (7247) 8224 44; Info: http://hikwww2.fzk.de/ehprg].

\section{1-5 August 2005}

54th Annual Denver X-ray Conference. Colorado Springs, Colorado, USA. Workshops on XRD and XRF (August 1-2). Invited talks (August 3-5). [Contact: Denise Flaherty, International Centre for Diffraction Data, 12 Campus Boulevard, Newtown Square, PA 19073-3273, USA. Tel: 1 (610) 325 9814; Fax: 1 (610) 325 9823; E-mail: flaherty@icdd.com; Info: http://www.dxcicdd.com].

\section{3-31 August 2005}

20th IUCr General Assembly and International Congress of Crystallography. Florence, Italy. [Contact: Congress Secretariat, XX Congress IUCr, Dipartimento di Energetica, Università di Firenze, via S. Marta 3, 50139 Firenze, Italy. Tel: 39 (055) 479 6240; Fax: 39 (055) 479 6342; E-mail: iucr@iucr2005.it; Info: http://www.iucr2005.it].

\section{9-13 October 2005}

32nd Annual Conference of the Federation of Analytical Chemistry and Spectroscopy Societies (FACSS). Quebec, Canada. [Contact: FACSS, Post Office Box 24379, Santa Fe, NM 87502, USA. Tel: 1 (505) 820 1648; Fax: 1 (505) 989 1073; E-mail: facss@facss.org; Info: http://www.facss.org].

28 November-2 December 2005

International Conference on Neutron Scattering. Sydney, Australia. [Contact: Brendan Kennedy, School of Chemistry, Building F11, University of Sydney, Sydney, NSW 2006, Australia. E-mail: b.kennedy@chem.usyd.edu.au; Info: http://www.icns2005.org/].

\section{Summer 2006}

23rd European Crystallographic Meeting. Leuven, Belgium.

\section{6-23 July 2006}

7th International Conference on the Occurrence, Properties, and Utilization of Natural Zeolites. Socorro, New 
Mexico, USA. [Contact: Robert Bowman, New Mexico Institute of Technology, Socorro, New Mexico, USA. E-mail: bowman@nmt.edu].
Summer 2008

21st IUCr General Assembly and International Congress of Crystallography. Osaka, Japan.

\section{Short Courses \& Workshops}

\section{4-17 March 2005}

ZEKAM Workshop 2005 Rietveld-Analytik. Bremen, Germany. Grundlagen und Anwendung. Ein Einführungskurs für Praktiker. Unterrichtssprache ist deutsche. [Contact: Dr. Michael Wendschuh, Zentrallabor für Kristallographie und Angewandte Materialwissenschaften im Fachbereich Geowissenshaften der Universität Bremen, Klagenfurter Strasse, 28359 Bremen, Germany; Tel: 49 (421) 21839 68; Fax: 49 (421) 21871 23; E-mail: zekam@uni-bremen.de; Info: http://www.brass.uni-bremen.de/RW2005/RW2005].

\section{8-29 March 2005}

Remote Access and Automation Workshop. Marysville, Australia. Part of Crystal24, which follows immediately at the same venue. Discussion centered on various large-scale data collection projects, typically involving synchrotron sources. [Contact: Info: http://xrsi.cmit.csiro.au/Crystal24/ mmsn_ws05_programme.html].

\section{2-6 May 2005}

ICDD X-ray Clinic: Practical X-ray Fluorescence Spectrometry. Newtown Square, Pennsylvania, USA. Sponsored by the International Centre for Diffraction Data. A week-long session directed to both relative newcomers and to more experienced users wishing to broaden their understanding of fundamental concepts and established procedures. Held in the ICDD Headquarters building. The $\$ 1600$ fee includes textbooks, laboratory notebook, use of computers, and daily lunch. [Contact: Leah Mooney, Education Coordinator, International Centre for Diffraction Data, 12 Campus Boulevard, Newtown Square, PA 19073-3273, USA. Tel: 1 (610) 325 9814; Fax: 1 (610) 325 9823; E-mail: clinics@icdd.com; Info: http://www.icdd.com/education/xrf.htm].

\section{2-26 May 2005}

9th EMAS Workshop on Modern Developments and Applications in Microbeam Analysis, held together with the 3rd Meeting of the International Union of Microbeam Analysis Societies. Florence, Italy. [Contact: European Microbeam Analysis Society Secretariat, University of Antwerp, Department of Chemistry, attn Mr. Luc Van't dack, Universiteitsplein 1, BE 2610 Antwerp-Wilrijk, Belgium. Tel: 32 (3) $820 \quad 23$ 43; Fax: 32 (3) 82023 43; E-mail: Luc.Vantdack@ua.ac.be; Info: http://www.emas-web.net/ Content/EMAS2005.htm].

\section{May 2005}

Workshop on Structure Solution and Refinement of Difficult Structures using Powder Diffraction. Orlando, Florida, USA. Sponsored by the Powder Diffraction Special Interest Group of the American Crystallo- graphic Association, and held immediately prior to the ACA Annual Meeting. Supported by the International Centre for Diffraction Data and the Canadian Institute of Neutron Scattering. [Contact: Nattamai Bhuvanesh at nbhuv@mail.chem.tamu.edu; Info: http:// www.chem.tamu.edu/xray/acawork/acaworkshop.html].

\section{5-10 June 2005}

IWPCPS-7 Seventh International Workshop on Physical Characterization of Pharmaceutical Solids. Kona, Hawaii, USA. [Contact: Adair Garis, Assa International, 3B East Lake Road, Danbury, CT 06811, USA. Tel: 1 (203) 312 0682; Fax: 1 (203) 312 0722; E-mail: assa.info@assainternational.com; Info: http:// www.assainternational.com/workshops/iwpcps_7/

iwpcps_7.cfm].

\section{6-10 June 2005}

ICDD X-ray Clinic: I. Fundamentals of X-ray Powder Diffraction. Newtown Square, Pennsylvania, USA. Sponsored by the International Centre for Diffraction Data. A week-long session directed to both relative newcomers and to more experienced users wishing to broaden their understanding of fundamental concepts and established procedures. Held in the ICDD Headquarters building. The $\$ 1600$ fee includes textbooks, laboratory notebook, use of computers, and daily lunch. [Contact: Leah Mooney, Education Coordinator, International Centre for Diffraction Data, 12 Campus Boulevard, Newtown Square, PA 19073-3273, USA. Tel: 1 (610) 325 9814; Fax: 1 (610) 325 9823; E-mail: clinics@icdd.com; Info: http://www.icdd.com/education/ xrd.htm].

\section{3-17 June 2005}

ICDD X-ray Clinic: II. Advanced Methods in X-ray Powder Diffraction. Newtown Square, Pennsylvania, USA. Sponsored by the International Centre for Diffraction Data. A week-long session designed for the experienced user and focusing on computer-based methods of qualitative and quantitative phase analysis. Held in the ICDD Headquarters building. The $\$ 1600$ fee includes textbook, laboratory notebook, use of computers, and daily lunch. [Contact: Leah Mooney, Education Coordinator, International Centre for Diffraction Data, 12 Campus Boulevard, Newtown Square, PA 19073-3273, USA. Tel: 1 (610) 325 9814; Fax: 1 (610) 325 9823; E-mail: clinics@icdd.com; Info: http:// www.icdd.com/education/xrd.htm].

\section{9-28 June 2005}

7th European Mineralogical Union School: Mineral Behaviour at Extreme Conditions. Heidelberg, Germany. A 